\title{
Reflection on Mathematics Classroom Discourse: The Perspective of Critical Pedagogy
}

\author{
Xiong Wang \\ Dept. of Secondary Education, University of Alberta \\ 116 St. and 85 Ave., Edmonton, AB, T6G 2R3, Canada \\ Tel: 1-587-759-3059_E-mail: xwang3@ualberta.ca
}

Received: June 25, 2015 Accepted: August 12, 2015 Published: August 14, 2015

doi:10.5296/10.5296/elr.v1i2.7900ＵRL: http://dx.doi.org/10.5296/elr.v1i2.7900

\begin{abstract}
A close attention has been paid to classroom discourse by researchers and teachers in the recent years. However, scanty research is conducted on the reflection of the mathematics classroom discourse from the perspective of critical pedagogy. Such angle will be adopted in this paper to address the research gap. The reflection on the mathematics classroom discourse is made by presenting the interactive discourse as an expectation of mathematics classroom teaching and by indicating the exclusive discourse and its costs with recourse to commenting the dominant mathematics classroom teaching. The presentation of interactive discourse and the indication of exclusive discourse are not about to offer a solution to dominant discourse but trigger the further consideration into the discourse in mathematics classroom.
\end{abstract}

Keywords: Classroom discourse, Mathematics classroom, Dominant discourse

\section{Introduction}

It has been known to us that the mathematical learning process is facilitated by appropriate use of language (MacGregor \& Stacey, 1995; Southwell, 1993, Kazemi \& Stipek, 2001). Wells (1999) has clarified two kinds of discourse function such as acting and understanding from the classroom observation. Acting mediates actions such as negotiating goals and means, monitoring other non-verbal forms of behavior, or managing the interpersonal relationships involved (Wells, 1999). When language acts in this way, mathematics meaning is negotiated as the purpose of the learning activity and its process could be perceived as a dynamic one of doing and communicating (Hucker, 1994). Understanding involves using language to reflect upon experiences because "language has the power to help children organize and link their 
partial understandings as they integrate and develop mathematical concepts" (Campbell and Rowan, 1997, p. 64). However, these two kinds of function are inseparable and interact on each other in reality so that one utterance would require choosing the representation from both aspects (Wells, 1999). Therefore, by using language in the classroom appropriately, students are expected to develop their mathematical understanding through giving meaning to new situation, reflecting the relation of the new meaning to previous experiences, and forging new connections.

However, scanty research was conducted on the reflection of the mathematics classroom discourse from the perspective of critical pedagogy. This paper tries to address the research gap by presenting the interactive discourse in mathematics teaching and learning through communications and by indicating the cost of exclusion of mathematics classroom discourse.

\section{The Interactive Discourse in Mathematics Teaching and Learning through Communications}

As for learning environment, critical pedagogy has claimed that "public schools are the democratic public spheres... teachers are the most responsible agents for fostering that education" (Giroux, 2014, para. 20). Regarding mathematics classroom teaching, the National Council of Teachers of Mathematics (NCTM, 2000) has advocated an inquiry-based learning environment within which students are not only encouraged to explore, conjecture, and solve problems but also facilitated to discuss and communicate their own ideas and thinking process. Thus, students have opportunities to construct their understanding within the learning community. Furthermore, NCTM (2000) has confirmed that mathematics classroom teaching should provide students the opportunities to make meaning through discourse. This notion is reinforced in mathematics education literatures by stressing that "mathematics learning as a social endeavor that is achieved through discourse (i.e., communication and interaction) in the classroom between teacher and students, and among students" (Ball, 1993; Cobb, Wood, \& Yackel, 1992, as cited by Griffin et al., 2013, p. 9).

Classroom discourse not merely enhances the sharing of understanding and new discernment but facilitates deeper analysis of mathematics as well (Manouchehri, 2007). In order to realize the importance of communication and interaction in mathematics classroom, Walshaw and Anthony (2008) categorized four discourse activities: to clarify the communication way between students and teachers in the classroom; to scaffold students' thinking to escalate forward; to fine-tune mathematical thinking through communications; and to shape mathematical argumentation and justification, which delineate the general picture of mathematics classroom teaching with emphasis upon discourse. The following excerpt could be a good example for the discourse activities that happened in a project-designing a golf course (Mukhopadhyay, 2009, p. 48):

\section{"Raoul: Okay so the golf course. Oh, I got it...let's just cut up a square piece of green and put it here.}

Aaron: Yeah, it's a golf course, it's flat.

Raoul: No just the ground's going to be flat. The buildings are going to be 
three-dimensional.

Aaron: No, you know let's make a big cube here. You know why? We'll make a door here.

Raoul: A cube without a top.

Aaron: A cube without a top. Good idea. Do it.

Raoul: You do it.

Aaron: Hey, I'm the one calculating around here."

According to the above conversations, two students have played different roles in the contribution to the project. For instance, Raoul brought out the ideas of cutting up "a square piece of green" and making flat ground and three dimensional buildings while Aaron reflected on Raoul's ideas and put forward the suggestion of making "a big cube" that was immediately improved by Raoul as "a cube without a top". The design plan "a cub without a top" was finally agreed with and confirmed as a great idea by Aaron who demonstrated that he would do the calculating for the project. Later on, in order to avoid power struggles from both students, the teacher acted as an expert to "lend value to all aspects of the project such as design and model construction and to support the position of those students who took on these roles" (Mukhopadhyay, 2009, p. 49). The students and the teacher participated in the communications through which the participatory democracy has been achieved. Furthermore, Mukhopadhyay (2009) suggested that, if the idea of democracy could be demonstrated, the focus had to be made on the type and quality of conversation in classroom teaching. The following was the participatory democracy represented by the interactive discourse in Figure 1. The discourse could be carried out not only between teacher and students but among students as well. More importantly, the direction of discourse moves not in a single way from teacher to students but in multi-way between teacher and students and among students.

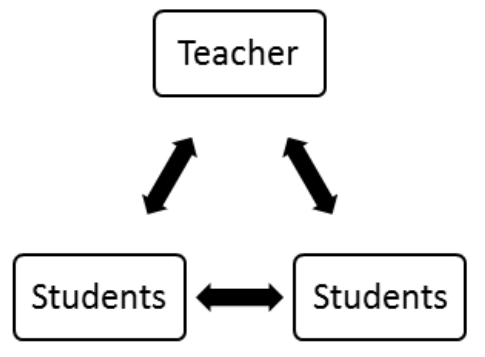

Figure 1. Interactive discourse

The triangle model shows the position and relationships of teacher and students in the interactive discourse and the interaction could emerge from the communications between teacher and students and among students. 


\section{The Exclusion of Mathematics Classroom Discourse and Its Cost}

Based on postmodern discourses, critical pedagogy provided educators with the critical perspective to "uncover the discursive environments within which the dominant discourses operate" (Kilderry, 2004, p. 35). For example, Wagner and Herbel-Eisenmann (2008) had made a critical analysis of how the word just was used to suppress and invite dialogue in mathematics classroom teaching and found that just mainly acted as a monoglossic tool suppressing dialogue. Based on the deliberate reflection on the nature of the school mathematics classroom, Gates and Vistro-Yu (2003) further indicated that the undemocratic features had been illustrated by such facts as dominant teaching method (chalk and talk), direct instruction and teacher-centered, transmissive teaching and dominant form communication (teacher talk). Also, Mukhopadhyay (2009) described the undemocratic features as the hegemonic script of mathematics classroom: reviewing homework and introducing the new topic; demonstrating "step" to solve problems on the new topic; working on sample problems; doing exercises; and assigning homework. Furthermore, Giroux (2014) argued that the repressive pedagogy killed the spirit, promoted conformity to authority rather than a democracy.

There could be an argument about that "it is at least equitable-that all children suffer equally" (Gates \& Vistro-Yu, 2003, p. 44) according to the diverse teaching method available to teachers. This could not be dire if Asian mathematics classroom was examined. For example, having statistically analyzed three Chinese mathematics lessons with other mathematics teachers to examine the interaction in the classroom, the author found that, in three periods of lessons, Teacher $\rightarrow$ Class interaction mode was heavily adopted in learning activities (Wang, Zuo, \& Lu, 2012), suggesting that teachers dominated the class during lectures. Interestingly, such result coincided with some other existing related research ones. For example, Huang (2006) has found that one of the characteristics in the Chinese classrooms teaching was large-sized class teaching during which the priority was given to interpretation and explanation of lecture. However, Chinese students, especially the students from Shanghai, China, for example, have also demonstrated their outstanding performance in the international tests (eg, PISA) even if Teacher $\rightarrow$ Class interaction mode was predominant in Chinese classroom teaching. It is obvious that the dominant discourse by teacher talk does not exert quite negative effect upon the students' mathematics performance, at least in tests. This could partially explain why the dominant discourse is still commonly seen in our daily mathematics classroom teaching.

Certainly, this is not the whole story of dominate discourse. What could be excluded from such undemocratic classroom teaching? On one hand, not all students had equal opportunity to have access to the forms of linguistic competence commanded by classroom (Gates \& Vistro-Yu, 2003) in that students from working class families were inherently not familiar with the formal school setting and required language and likely to fail in public school (Giroux, 2014). On the other hand, based on the hegemonic script of mathematics classroom, Mukhopadhyay (2009) argued that this "script" affected students differently-"empowering some, while marginalizing others" (Mukhopadhyay, 2008, as cited by Mukhopadhyay, 2009, p. 45). For example, some students who did not have the ability to remember operational 
formula precisely and to apply it to algorithms were viewed as marginalized members of the classroom community (Mukhopadhyay, 2009).

Another example is taken from a Singaporean elementary lesson (Wang \& Fang, 2008) I have observed. In a discourse sequence, the learning activity was tasked to draw a line to show half in a strip folded 3 times. The instruction was created to draw a line using pencil and ruler to show half of a strip. Yet, some students failed to understand the teacher's instruction and did some wrong manipulations. For example, one of the students realized his wrong manipulation (cut the paper) and tried to seek help from the teacher "teacher, go and cut then cut wrongly (Note 1)". The teacher impatiently replied "Cut? Why you cut the paper? I never ask you to cut (Note 2)" Then the student cravenly pointed to his deskmate. And again, the teacher dictatorially emphasized that "no need to cut the paper. Just fold it. I give you another one. Why you cut the paper? (Note 3)" and closed the interaction of this sequence accordingly. The above interaction showed that some students were mistaken in the manipulation without comprehending its instruction. In fact, the teacher only required the student to follow his instruction in the feedback rather than understanding the instruction and giving reasons to his wrong manipulation. Consequently, the interaction did not produce a satisfying result and apply substantial mathematical meaning needed for the concept construction. The whole interaction reinforced the teacher's dominant discourse.

The exclusion is not only the chance of developing students' own understanding but their experiences as well. For instance, the student making mistakes in the discourse sequence had to give up all the previous manipulation experiences-cutting papers to follow the teacher's instruction. In fact, cutting papers was an alternative way to express the fractions. Certainly, the student' experiential narratives could be ignored on the teacher-student relationship, which would lead to the potential marginalization of this kind of student. Thus, for students, especially for marginalized ones, their voices and experiences could exclude from the undemocratic mathematics classroom discourse.

\section{Discussion}

Less attention has already been paid to the reflection on the discourse in mathematics classroom teaching despite many researches on it. Critical pedagogy advocating removal of the hegemonic barriers from the classroom provides us with a critical perspective of reflecting upon the detailed interaction and rethinking about the dominant discourse from teachers, in particular, about the cost of exclusive discourse, in the mathematics classroom teaching. In fact, teachers intended to encourage students to participate in discourse as much as possible. For example, Pimm (1984) explored that we were so often invoked in the mathematics classroom teaching to build a learning community. However, the hegemonic phenomenon was so obviously existent that we could not do anything only to wait for the democracy occurrence in the mathematics classroom. The presentation of interactive discourse and the indication of exclusive discourse provided here are expected to be regarded as a trigger for further consideration into the dominant discourse in mathematics classroom teaching. 


\section{Acknowledgements}

2015, Vol. 1, No. 2

The research is financed by Humanities and Social Science Research Project of the Ministry of Education, P.R. China. No. 13YJC880075.

\section{References}

Campbell, P., \& Rowan, T. (1997). Teacher questions + student language + diversity = mathematical power. In J. Trentacosta \& M. Kenney (Eds.), Multicultural and gender equity in the mathematical classroom: The Gift of Diversity (pp. 60-70). Reston, VA: National Council of Teachers of Mathematics.

Griffin, C. C., League, M.B., Griffin, V. L., \& Bae, J. (2013). Discourse Practices in Inclusive Elementary Mathematics Classrooms. Learning Disability Quarterly, 36(1), 9-20. http://dx.doi.org/10.1177/0731948712465188

Gates, P., \& Vistro-Yu, C. P. (2003). Is mathematics for all? In A. J. Bishop, M. A. Clements, C. Keitel, J. Kilpatrick, \& F. K. S. Leung (Eds.), Second international handbook of mathematics education (Vol. 1, pp. 31-73). Dordrecht, the Netherlands: Kluwer. http://dx.doi.org/10.1007/978-94-010-0273-8_3

Giroux, H. A. (2014). When schools become dead zones of the imagination: A critical pedagogy manifesto. Truthout, 06 November. http://dx.doi.org/10.2304/pfie.2014.12.4.491

Huang, J. (2006). The international comparison in mathematics classroom: Methodology, discovery and enlightenment. The Proceeding of annual conference of the National Research Association of Teacher Education, 2006. Retrieved December 10, 2014, from http://math.fjnu.edu.cn/zxsx/mathedu2006

Hucker, J. (1994). Creating paths to mathematical literacy: A.S.B./A.P.P.A. Travelling Fellowship 1994 Report. Auckland, New Zealand: Author.

Kazemi, E., \& Stipek, D. (2001). Promoting conceptual thinking in four upper-elementary mathematics classrooms. Elementary School Journal, 102, 59-80. http://dx.doi.org/10.1086/499693

Kilderry, A. (2004). Critical pedagogy: A useful framework for thinking about early childhood curriculum. Australian Journal of Early Childhood, 29(4), 33-37.

MacGregor, M., \& Stacey, K. (1995). The effect of different approaches to algebra on students' perceptions of functional relationships. Mathematics Education Research Journal, 7(1), 69-85. http://dx.doi.org/10.1007/BF03217276

Manouchehri, A. (2007). Inquiry-discourse mathematics instruction. Mathematics Teacher, 101, 290-300.

Mukhopadhyay, S. (2009). Participatory and dialogue democracy in U.S. mathematics classroom. Democracy \& Education, 18(3), 45-50.

National Council of Teachers of Mathematics (NCTM). (2000). Principles and Standards for 


\section{Macrothink \\ Education and Linguistics Research \\ ISSN 2377-1356 \\ 2015, Vol. 1, No. 2}

School Mathematics. Reston, Va.: NCTM.

Pimm, D. (1984). Who is "'we"? Mathematics Teaching, 107, 39-42.

Southwell, B. (1993). Development and assessment of student writing. In M. Stephens, A. Waywood, D. Clarke, \& J. Izard (Eds), Communicating mathematics: Perspectives from classroom practice and current research (pp. 223-236). Melbourne: The Australian Council for Educational Research Ltd.

Wagner, David and Herbel-Eisenmann, Beth. (2008). 'Just don't:' The suppression and invitation of dialogue in the mathematics classroom. Educational Studies in Mathematics, 67(2), 143-157. http://dx.doi.org/10.1007/s10649-007-9097-x

Walshaw, M., \& Anthony, G. (2008). The teacher's role in classroom discourse: A review of recent research into mathematics classrooms. Review of Educational Research, 78, 516-551. http://dx.doi.org/10.3102/0034654308320292

Wang, X., Zuo, X., \& Lu, C. (2013). The teaching strategies of promoting students' understanding in geometric proof-The perspective of developing Chinese localized mathematics education. Proceeding of 6th East Asia Regional Conference on Mathematics Education (EARCOME6), 214-223.

Wang, X., \& Fang, Y. (2008). Quantitative and qualitative representations of teaching improvement in research lessons: Representation pattern and lesson orchestration. Paper represented at the Asia Pacific Educational Research Association (APERA) Conference 2008, Singapore.

Wells, G. (1999). Dialogic inquiry: Towards a sociocultural practice and theory of education. Cambridge, Cambridge University Press.

\section{Notes}

Note 1. The statement is shown in the 622th line in the lesson transcriptions.

Note 2. The statement is shown in the 624th line in the lesson transcriptions.

Note 3. The statement is shown in the 628th line in the lesson transcriptions.

\section{Copyright Disclaimer}

Copyright reserved by Xiong Wang.

This article is an open-access article distributed under the terms and conditions of the Creative Commons Attribution license (http://creativecommons.org/licenses/by/3.0/). 